\title{
TO EVALUATE THE ANTI-INFLAMMATORY ACTIVITY OF ETHANOLIC EXTRACT OF LEAVES OF MIKANIA MICRANTHA ON EXPERIMENTAL ANIMAL MODELS
}

\author{
Chinmoyee Deori' ${ }^{1}$ Geetamoni Dutta², Swarnamoni Das ${ }^{3}$, Daisy Phukan ${ }^{4}$, Gaurov Gogoi ${ }^{5}$ \\ ${ }^{1}$ Associate Professor, Department of Pharmacology, AMCH, Dibrugarh. \\ ${ }^{2}$ Assistant Professor, Department of Pharmacology, AMCH, Dibrugarh. \\ 3 Professor, Department of Pharmacology, AMCH, Dibrugarh. \\ ${ }^{4}$ Professor, Department of Pharmacology, SMCH, Silchar. \\ ${ }^{5}$ Demonstrator, Department of Pharmacology, AMCH, Dibrugarh.
}

ABSTRACT

\section{BACKGROUND}

Different parts of the plant Mikania micrantha are traditionally used to treat several diseases like dysentery, body sprain, diabetes, snake bites, itches, gout, flatulence, rheumatism and cancer. Therefore, the present study was undertaken to evaluate the antiinflammatory activity of the Ethanolic Extracts of leaves of Mikania micrantha (EEMM) on carrageenan-induced rat paw oedema, granuloma-pouch method and adjuvant-induced chronic arthritis on experimental animals.

\section{MATERIALS AND METHODS}

Plants of Mikania micrantha were collected from the campus of Assam Medical College, Dibrugarh, Assam. The extract of Mikania micrantha leaves was prepared by percolation method using 95\% alcohol. Acute oral toxicity test of the extract was performed as per OECD 423 (OECD Guidelines, 2001). Acute inflammation was studied by carrageenan-induced rat paw oedema method; subacute inflammation was studied by Granuloma pouch method and chronic inflammation was studied by Freund's complete adjuvant-induced arthritis method. Aspirin $100 \mathrm{mg} / \mathrm{kg}$ was taken as a standard drug. A control group is maintained in all the above mentioned models.

\section{RESULTS}

The results were analysed by ANOVA followed by Dunnett's multiple comparison test. EEMM in doses $200-400 \mathrm{mg} / \mathrm{kg}$ produced dose dependent and significant $(\mathrm{p}<0.05)$ reduction of paw oedema in carrageenan-induced acute and sub-acute inflammation in comparison to control. EEMM is not effective in chronic arthritis model in dose-dependent manner.

\section{CONCLUSION}

The present study indicates that EEMM has significant anti-inflammatory activity.

\section{KEYWORDS}

Ethanolic Extract, Mikania Micrantha, Anti-Inflammatory, Carrageenan, Granuloma Pouch, Freund's Complete Adjuvant.

HOW TO CITE THIS ARTICLE: Deori C, Dutta G, Das S, et al. To evaluate the anti-inflammatory activity of ethanolic extract of leaves of mikania micrantha on experimental animal models. J. Evolution Med. Dent. Sci. 2017;6(50):3818-3821, DOI: $10.14260 /$ Jemds/2017/825

\section{BACKGROUND}

Inflammation is a complex reaction to injurious agents such as microbes and damaged usually necrotic cells that consist of vascular responses, migration and activation of leucocytes and systemic reactions. ${ }^{(1)}$

The complete process of inflammation consists of three phases- (i) Dilatation and increased permeability of small blood vessels resulting in oedema and swelling; (ii) Emigration of leucocytes and cellular infiltration; and (iii) Proliferation of fibroblast and synthesis of new connective tissues.

Financial or Other, Competing Interest: None.

Submission 03-04-2017, Peer Review 10-06-2017,

Acceptance 16-06-2017, Published 22-06-2017.

Corresponding Author:

Dr. Chinmoyee Deori,

Department of Pharmacology,

Assam Medical College and Hospital,

Dibrugarh-786002, Assam.

E-mail: deorichinmoyee@gmail.com

DOI: $10.14260 /$ jemds $/ 2017 / 825$
Mikania micrantha is an extremely fast growing perennial creeping weed. Its native distribution is in Central and South America.(2) Different parts of the plant Mikania micrantha are used to treat fever, jaundice, dysentery, rheumatism, colds, respiratory diseases and scorpion stings. (3) The leaves have been reported as good haemostatic agents.(4) In India, the plant is used by different ethnic communities for treatment of dysentery, body sprain, diabetes, snake bites, itches, gout, flatulence, rheumatism and cancer.(5) The plant is enriched with several sesquiterpene lactones and phenolic compounds. Active constituents isolated from the plant are the alkaloids, sterols, diterpenes, polyphenols, flavonoids, sesquiterpene lactones, etc. The most common phytosterols detected in aerial parts of this plant are stigmasterol, luperol and sitosterol.(6) Terpenoids like amyrin and friedelin are abundant in Mikania micrantha. Traditionally, the decoction of leaves has been used to treat painful conditions.(7)

\section{MATERIALS AND METHODS \\ Plant Material}

The study was carried out in the Department of Pharmacology. Fresh matured leaves of Mikania micrantha were collected from the campus of Assam Medical College, Dibrugarh, Assam. The plants were authenticated by Prof. M. 
Islam, Department of Life Sciences, Dibrugarh University, Assam.

\section{Plant Extract}

Fresh leaves of $3 \mathrm{~kg}$ of Mikania micrantha were air dried at room temperature, powdered by grinder and soaked in $95 \%$ alcohol, allowed to stand for 6 hours in an air tight container. After 24 hours of maceration, slow percolation was done and then the extracts were prepared by evaporation in a rotary evaporator under controlled temperature and reduced pressure. When completely dry the extract was scraped out, weighed and stored.(8)

\section{Animals}

All the animals used in the study were procured from Central Animal House, Assam Medical College and Hospital, Dibrugarh, Assam, during the months of December and January 2009. Duration of my study was 2 months. The study was conducted in accordance with CPCSEA (Committee for the Purpose of Control and Supervision of Experiment on Animals) guidelines and the study was approved by the Institutional Animal Ethical Committee (Registration No. 634/02/a/CPCSEA). They were fed with standard diet and water ad libitum was provided. Experimental animals used were healthy albino rats of the species Rattus norvegicus of either sex weighing $150-200$ gm. Minimum numbers of animals (at least 5) were used in this study for achieving the hypothesis or to find a significant difference between the compared groups through a statistical analysis.(9)

\section{Acute Toxicity Study}

Acute toxicity test was done for the ethanolic extract of Mikania micrantha following OECD 423 guidelines.(10) An arbitrary dose of $500 \mathrm{mg} / \mathrm{kg}$ was selected for the study, as the extract was found safe even at doses more than $2000 \mathrm{mg} / \mathrm{kg}$ without any sign of toxicity or mortality.

Anti-inflammatory Studies for each Experiment, the Animals were divided into 4 Groups with 6 Animals in each Group

- Group-A (Control) received 3\% gum acacia $10 \mathrm{~mL} / \mathrm{kg}$ p.o.

- Group-B (Test-1) received EEMM leaf extract $200 \mathrm{mg} / \mathrm{kg}$ p.o.

- $\quad$ Group-C (Test-2) received EEMM leaf extract $400 \mathrm{mg} / \mathrm{kg}$ p.o.

- $\quad$ Group-D (Standard) received aspirin $100 \mathrm{mg} / \mathrm{kg}$ p.o.

All the drugs were administered orally and the volume of medicaments kept constant at $10 \mathrm{~mL} / \mathrm{kg}$ body weight of the animals.

\section{(a) Anti-Inflammatory Study against Acute Inflammation} The anti-inflammatory activity of EEMM against acute inflammation was tested by carrageenan-induced rat paw oedema method. Acute inflammation was produced by subplantar injection of $0.1 \mathrm{~mL}$ of freshly prepared $1 \%$ carrageenan suspension in normal saline in the right hind paw of rats in each group. The animals were treated with 3\% gum acacia, EEMM or aspirin in the respective groups, $1 \mathrm{~h}$ before carrageenan injection. The paw volume was measured plethysmometrically as described by Chattopadhyay et al at " 0 " $\mathrm{h}$ and then at $1^{\text {st }}, 2^{\text {nd }}, 3^{\text {rd }}$ and $4^{\text {th }}$ after carrageenan injection.(11) Increase in paw oedema was measured as the difference between the paw volume at " 0 " $h$ and paw volume at the end of each hour. The drugs were administered orally in the respective groups one hour before carrageenan injection. The percentage inhibition of the rat paw oedema was calculated after each hour of carrageenan injection up to 4 hours by the formula.(12)

(Control mean - Treated mean)

\% Inhibition= - Control mean

The data were statistically analysed using One-Way ANOVA followed by Dunnett's multiple comparison test and " $\mathrm{P}$ " values less than 0.05 were considered significant.

\section{(b) Anti-Inflammatory Study against Sub-Acute Inflammation}

The anti-inflammatory activity of EEMM leaves against subacute inflammation was tested by Granuloma pouch method. Rats were anaesthetised with ether and subcutaneous dorsal air pouches were then prepared at the backs by injecting 20 $\mathrm{mL}$ of air with the help of a fine needle after proper shaving and disinfection. Then $1 \mathrm{~mL}$ of $20 \%$ carrageenan suspension in sesame oil was injected into each pouch; $48 \mathrm{~h}$ later air was withdrawn from the pouch and $72 \mathrm{~h}$ later any resulting adhesions were broken.

The animals were treated with 3\% gum acacia, EEMM or aspirin in the respective groups for 4 days starting from the day of pouch formation. On the 5th day, the animals were sacrificed under ether anaesthesia. The pouch was opened and exudates were sucked out and the amount measured in glass cylinders. The average values of the exudates of the control and the test groups were calculated. The percentage inhibition was then calculated for all the groups.(13)

\section{c) Anti-Inflammatory Study against Chronic Inflammation}

The anti-inflammatory activity of EEMM against chronic inflammation was tested by Freund's adjuvant-induced arthritis method in rats. On Day 1, the animals were injected into the subplantar region of the left hind paw with $0.1 \mathrm{~mL}$ of complete Freund's adjuvant. Dosing with the test compounds or the standards to the respective groups was started on the same day and continued for 12 days. The paw volumes of both sides and the body weights were recorded on the day of injection. The paw volumes were measured plethysmographically as in the paw oedema test. On Day 5 and for the secondary lesions, the volume of the injected paw was measured again indicating the primary lesion and the influence of the therapeutic agent on this phase. The severity of the disease was followed by measurement of the noninjected paw (Secondary lesions) with a plethysmometer. Purposely, from Day 13 to 21, the animals were not administered with the test compound or the standard. The non-injected paw volume and the body weight were measured on $21^{\text {st }}$ day ${ }^{[12]}$ and the polyarthritis severity score was graded on 0 to 4 : $0=$ No swelling; $1=$ Phalanx joint involvement; $2=$ Phalanx joint and all digits involvement; $3=$ 
Whole region of the ankle involvement; $4=$ Paw and ankle involvement. The joint score was 12 maximum including 3 secondary arthritis paws for each rat.(14)

1. For primary lesions: The $\%$ inhibition of paw volume of the injected right paw over control was measured at the $5^{\text {th }}$ day of experiment.

2. For secondary lesions: The $\%$ inhibition of paw volume of non-injected left paw over control was measured at the $21^{\text {st }}$ day of experiment.
An Arthritis Index was calculated as the sum of the scores as indicated above for each animal.

Statistical analysis was done using One-Way ANOVA followed by Dunnett's Multiple Comparison test. Significance level of $<0.05$ was considered as significant.(15)

\section{RESULTS}

In acute oral toxicity tests, the LD50 of EEMM was found to be more than $2000 \mathrm{mg} / \mathrm{kg}$.

\begin{tabular}{|c|c|c|c|c|c|}
\hline \multirow[t]{2}{*}{ Group } & \multirow[t]{2}{*}{ Drug Dose P.0. } & \multicolumn{4}{|c|}{$\begin{array}{c}\text { Mean Increase in Paw Volume } \\
(\text { Mean } \pm \text { SEM) }(\mathrm{mL})(\% \text { Inhibition within Parentheses })\end{array}$} \\
\hline & & $1^{\text {st }} \mathrm{hr}$ & $2^{\text {nd }} \mathrm{hr}$ & $3^{\text {rd }} \mathrm{hr}$ & $\mathbf{4}^{\text {th }} \mathbf{h r}$ \\
\hline A (Control) & $10 \mathrm{~mL} / \mathrm{kg}$ & $0.20 \pm 0.02$ & $0.28 \pm 0.01$ & $0.54 \pm 0.04$ & $0.30 \pm 0.05$ \\
\hline B (EEMM) & $200 \mathrm{mg} / \mathrm{kg}$ & $0.16 \pm 0.04^{\mathrm{ab}}$ & $0.22 \pm 0.01^{\mathrm{ab}}$ & $0.34 \pm 0.08^{\mathrm{ab}}$ & $0.20 \pm 0.07 \mathrm{ab}$ \\
\hline C (EEMM) & $400 \mathrm{mg} / \mathrm{kg}$ & $0.16 \pm 0.04^{\mathrm{ab}}$ & $0.15 \pm 0.06^{\mathrm{ab}}$ & $0.24 \pm 0.04^{\mathrm{ab}}$ & $0.14 \pm 0.01^{\mathrm{ab}}$ \\
\hline D (Aspirin) & $100 \mathrm{mg} / \mathrm{kg}$ & $0.09 \pm 0.01^{\mathrm{ab}}$ & $0.11 \pm 0.07 \mathrm{ab}$ & $0.20 \pm 0.02^{\mathrm{ab}}$ & $0.11 \pm 0.01^{\mathrm{ab}}$ \\
\hline \multirow{3}{*}{$\begin{array}{l}\text { One-Way } \\
\text { ANOVA }\end{array}$} & $\mathrm{F}$ & 285 & 400.4 & 175.9 & 355.9 \\
\hline & $\mathrm{Df}$ & 20.3 & 20.3 & 20.3 & 20.3 \\
\hline & $\mathrm{P}$ & $<0.05$ & $<0.05$ & $<0.05$ & $<0.05$ \\
\hline
\end{tabular}

EEMM, SEM- Standard Error of Mean, ANOVA- Analysis of Variance, Values= Mean \pm SEM, $n=6$ in each group, a- $p<0.05$ when compared with controls, $\mathrm{b}-\mathrm{p}<0.05$ when compared with standard, ANOVA followed by Dunnett's multiple comparison test.

\begin{tabular}{|c|c|c|c|}
\hline Group & Drug Dose P.O. & Mean Volume of Exudates (Mean \pm SEM) (mL) & Inhibition of Exudates Formation (\%) \\
\hline A (Control) & $10 \mathrm{~mL} / \mathrm{kg}$ & $3.60 \pm 0.04$ & 38.88 \\
\hline B (EEMM) & $200 \mathrm{mg} / \mathrm{kg}$ & $2.20 \pm 0.25^{\mathrm{ab}}$ & 63.88 \\
\hline C (EEMM) & $400 \mathrm{mg} / \mathrm{kg}$ & $1.30 \pm 0.03^{\mathrm{ab}}$ & 70.83 \\
\hline D (Aspirin) & $100 \mathrm{mg} / \mathrm{kg}$ & $1.05 \pm 0.02^{\mathrm{a}}$ & \\
\hline \multirow{2}{*}{$\begin{array}{c}\text { One-Way } \\
\text { ANOVA }\end{array}$} & $\mathrm{F}$ & 936.9 & \\
\cline { 2 - 4 } & $\mathrm{Df}$ & 20.3 & \\
\cline { 2 - 4 } & $\mathrm{P}$ & $<0.05$ & \\
\hline \multicolumn{4}{|c|}{ Table 2. Anti-Inflammatory Activity of the Ethanolic Extract of Mikania micrantha } \\
on Sub-Acute Inflammation by Granuloma Pouch Method
\end{tabular}

EEMM, SEM- Standard Error of Mean, ANOVA- Analysis of Variance, Values= Mean \pm SEM, $n=6$ in each group, a- $p<0.05$ when compared with controls, $\mathrm{b}-\mathrm{p}<0.05$ when compared with standard, ANOVA followed by Dunnett's multiple comparison test.

\begin{tabular}{|c|c|c|c|c|c|c|c|}
\hline \multirow[b]{2}{*}{ Group } & \multirow[b]{2}{*}{$\begin{array}{l}\text { Drug } \\
\text { Dose }\end{array}$} & \multicolumn{2}{|c|}{ Injected Paw (mL) } & \multicolumn{2}{|c|}{ Non-Injected Paw (mL) } & \multirow{2}{*}{$\begin{array}{l}\text { Weight Change } \\
\text { on } 21^{\text {st }} \text { Day } \\
\text { (\% Change in } \\
\text { Parentheses) }\end{array}$} & \multirow[b]{2}{*}{$\begin{array}{l}\text { Arthritis } \\
\text { Index }\end{array}$} \\
\hline & & $1^{\text {st }}$ Day & $5^{\text {th }}$ Day & $1^{\text {st }}$ Day & 21 st Day & & \\
\hline A (Control) & $10 \mathrm{~mL} / \mathrm{kg}$ & $1.00 \pm 0.01$ & $2.12 \pm 0.01$ & $1.00 \pm 0.02$ & $1.35 \pm 0.02$ & $-30.83 \pm 1.40$ & $10.00 \pm 0.52$ \\
\hline B (EEMM) & $200 \mathrm{mg} / \mathrm{kg}$ & $1.02 \pm 0.02$ & $2.04 \pm 0.02$ & $1.02 \pm 0.01$ & $1.39 \pm 0.02$ & $-28.00 \pm 1.24^{\mathrm{ab}}$ & $9.83 \pm 0.48$ \\
\hline C (EEMM) & $400 \mathrm{mg} / \mathrm{kg}$ & $1.02 \pm 0.01$ & $1.92 \pm 0.02^{\mathrm{a}}$ & $1.022 \pm 0.01$ & $1.36 \pm 0.02$ & $-27.83 \pm 1.33^{\mathrm{ab}}$ & $8.50 \pm 0.26$ \\
\hline D (Aspirin) & $100 \mathrm{mg} / \mathrm{kg}$ & $1.01 \pm 0.02$ & $1.73 \pm 0.03^{\mathrm{a}}$ & $1.015 \pm 0.01$ & $1.02 \pm 0.01^{\mathrm{a}}$ & $-50.00 \pm 2.08^{a}$ & $2.83 \pm 0.31^{\mathrm{a}}$ \\
\hline \multirow{3}{*}{$\begin{array}{c}\text { One-Way } \\
\text { ANOVA }\end{array}$} & $\mathrm{F}$ & 0.35 & 47.54 & 0.34 & 61.18 & 80.56 & 201.7 \\
\hline & Df & 20,3 & 20,3 & 20,3 & 20,3 & 20,3 & 20,3 \\
\hline & $\mathrm{P}$ & $>0.05$ & $<0.05$ & $>0.05$ & $<0.05$ & $<0.05$ & $<0.05$ \\
\hline & Table & $\begin{array}{r}\text { nti-Inflam } \\
\text { Chron }\end{array}$ & ory Activity & thanolic EX & $\begin{array}{l}\text { of Mikania } \\
\text { ed Arthritis }\end{array}$ & rantha on & \\
\hline
\end{tabular}

EEMM, SEM- Standard Error of Mean, ANOVA- Analysis of Variance, Values $=$ Mean \pm SEM, $n=6$ in each group, $a-p>0.05$ when compared with controls, $b-p>0.05$ when compared with standard, ANOVA followed by Dunnett's multiple comparison test.

\section{DISCUSSION}

Our study showed that ethanolic extracts of the leaves of Mikania micrantha produced significant acute and sub-acute anti-inflammatory activity against carrageenan-induced acute inflammation and at the $4^{\text {th }} \mathrm{h}$ the effect of EEMM at the dose of $200 \mathrm{mg} / \mathrm{kg}$ showed almost similar to the aspirin at the dose of $100 \mathrm{mg} / \mathrm{kg}$ when given orally. 
In Granuloma pouch method, ethanolic extracts of EEMM leaves showed highly significant anti-inflammatory activity against sub-acute inflammation. The effect of EEMM at the dose of $400 \mathrm{mg} / \mathrm{kg}$ was almost similar to that of aspirin 100 $\mathrm{mg} / \mathrm{kg}$. In Freund's complete adjuvant-induced arthritis model, EEMM at the dose of $200 \mathrm{mg} / \mathrm{kg}$ and $400 \mathrm{mg} / \mathrm{kg}$ showed no significant reduction of paw oedema formation.

EEMM at the doses [200 mg/kg and $400 \mathrm{mg} / \mathrm{kg}]$ showed no significant reduction of the arthritis index and significantly reduced the decrease in weight in the adjuvant arthritis rats as compared to the control group as on 21st day of adjuvant injection. Ulcers produced by aspirin may have impact on food and possibly water intake leading to increased weight loss in the standard group.

However, a decreased appetite could also contribute to the weight loss observed since this phenomenon is an established feature of the active immune phase arthritis in humans.(16) Adjuvant arthritis is characterised by weight $\operatorname{loss}^{(17)}$ and body weight loss is associated with increased production of pro-inflammatory cytokines such as TNF- $\alpha(\mathrm{P}<$ 0.001) and interleukin-1.

\section{CONCLUSION}

The data obtained from different groups were compared for statistical significance by using One-Way ANOVA followed by Dunnett's ' $t$ ' test. All the findings suggest that ethanolic extract of Mikania micrantha leaves possess significant antiinflammatory activity against acute and sub-acute inflammation, but there is no significance against chronic inflammation in various experimental animal models.

\section{ACKNOWLEDGEMENT}

We are thankful to Dr. M. Islam, Department of Life Sciences, Dibrugarh University, Assam, for helping us with the taxonomical identification of the plant. We are also thankful to laboratory staff of Pharmacology Department, Assam Medical College, Dibrugarh, Assam.

\section{REFERENCES}

[1] Kmer V, Abdul AK, Fausto N. Acute and chronic inflammation. $7^{\text {th }}$ edn. Robins and cotron pathologic basis of disease. Elsevier: New Delhi 2004:47-113.

[2] Rufatto LC, Gower A, Schwambach J, et al. Genus mikania: chemical composition and phytotherapeutical activity. Braz J Pharmacog 2012;22(6):1384-403.

[3] Li Y, Li J, Li Y, et al. Antimicrobial constituents of the leaves of mikania micrantha H.B.K. Plos ONE $2013 ; 8(10)$.
[4] Bhardwaj S, Gaklar SK. Ethnomedicinal plants used by the tribal's of mizoram to cure cuts and wounds. India J Tradit Knowl 2005;4(1):75-80.

[5] Herz W, Srinivasan A, Kalyanaraman PS. Mikanocryptin, a new guianolide from mikania phytochemistry 1975;14(1):233-7s.

[6] Tripathi R, Khan M, Yadav A. Biology of mikania micrantha H.B.K: a reviews, CAB International. Scientific Research 2012:99-107.

[7] Remington. Solution, emulsion, suspension and extracts. The science and practice of pharmacy. 19th edn. Mack Publishind Company: Pennsylvania 1995:1495-523.

[8] Medhi B, Prakash A. Practical manual of experimental and clinical pharmacology. $1^{\text {st }}$ edn. Jaypee Brothers, Medical Publishers Pvt. Limited 2010:p 40.

[9] Agus S. The potency of piperne as antiinflammatory and analgesic in rats and mice. Folia Med Indonesia 2005;41(3):190-4.

[10] OECD. In: Acute oral toxicity-acute oral toxic class method. Guideline 423, eleventh addendum to the OECD guidelines for testing of chemicals, organization for economic co-operation and development: Paris 2001.

[11] Olajide OA, Awe SO, Makinde JM, et al. Studies on the anti-inflammatory, antipyretic and analgesic properties of alstonia boonei stem bark. J Ethnopharmacol 2000:71(1-2):179-86.

[12] Gu WZ, Brandwein SR. Inhibition of type II collageninduced arthritis in rats by triptolide. Int J Immunopharmacol 1998;20(8):389-400.

[13] Vogel HG. Antiarthrotic and immunomodulatory activity. $2^{\text {nd }}$ edn. Drug discovery and evaluation. Completely revised and enlarged. Germany: Springer publishing 2002:802-5.

[14] Cunningham ET, De Souza EB. Interleukin 1 receptors in the brain and endocrine tissues. Immunology today 1993;14(4):171-6.

[15] Campo GM, Avenoso A, Campo S, et al. Efficacy of treatment with glycosaminoglycans on experimental collagen- induced arthritis in rats. Arthritis Res Ther 2003;5(3):R122-31.

[16] Roubenoff R, Freeman LM, Smith DE, et al. Adjuvant arthritis as a model of inflammatory cachexia. Arth Rheum 1997;40(3):534-9.

[17] Pomposelli JJ, Flores EA, Bistrian BR. Role of biochemical mediators in clinical nutrition and surgical metabolism. J Parenter Enteral Nutr 1998;12(2):212-18. 